\title{
URBAN AQUATIC ECOSYSTEMS AS A FACTOR OF THE SPREAD OF ANTIBIOTIC RESISTANT MICROORGANISMS AND RESISTANCE GENES
}

Marianna SAVENKO * and Maryna KRYVTSOVA **

* Uzhhorod National University, Biological Faculty, Department of Genetics, Plant Physiology and Microbiology, Voloshina, 32, Uzhhorod, Ukraine, UA-88000, mariannasavenko7@gmail.com, ORCID: orcid.org/0000-0003-4434-182

** Uzhhorod National University, Biological Faculty, Department of Genetics, Plant Physiology and Microbiology, Voloshina, 32, Uzhhorod, Ukraine, UA-88000, maryna.krivcova@gmail.com, ORCID: 0000-0001-8454-2509

DOI: 10.2478/trser-2021-0009

KEYWORDS: co-resistance, water quality, antibiotic resistance microorganisms, drinking water sources, resistant genes.

\section{ABSTRACT}

In this work, studies have been conducted to detect antibiotic resistance microorganisms and resistance genes in the natural waters of the Uzh River, which flows in the Carpathian region (Ukraine) and flows into the Laborec River in the territory of Slovakia. Among the most common microorganisms of the Uzh River, there has been a high level of resistance to tetracyclines, $\beta$-lactams, and antibiotics of the last line of defence (carbapenems, fourth-generation fluoroquinolones). The results of molecular genetic analysis indicate the presence of resistance genes bla tet-M, bla CTX-M, bla TEM, and bla KPC in microorganisms of the Enterobacteriaceae family.

ZUSAMMENFASSUNG: Urbane aquatische Ökosysteme als Faktor für die Verbreitung Antibiotika resistenter Organismen und resistenter Genen.

Die vorliegende Arbeit befasst sich mit den Ergebnissen von Untersuchungen über Nachweise Antibiotika resistenter Mikroorganismen und resistenter Gene in den natürlichen Gewässern des Uzh-Flusses, in der Karpatenregion der Ukraine entspringt und auf dem Gebiet der Slowakei in den Laborec-Fluss mündet. Unter den häufigsten nachgewiesenen Mikroorganismen des Uzh-Flusses fanden sich solche, deren Resistenz gegen Tetracycline, $\beta$ Lactame und Antibiotika der letzten Aktivitätslinie (Carbapeneme, Fluorchinolone der vierten Generation) hoch war. Die Ergebnisse der molekulargenetischen Analyse weisen auf das Vorkommen der resistenten Gene bla tet-M, bla CTX-M, bla TEM und bla KPC in Mikroorganismen der Familie der Enterobacteriaceae hin.

REZUMAT: Ecosisteme urbane acvatice ca factor al răspândirii microrganismelor rezistente la antibiotice şi a genelor de rezistenţă.

În această lucrare, au fost efectuate studii pentru a detecta microorganismele cu rezistență la antibiotice și genele de rezistență în apele naturale ale râului Uzh, care curge în regiunea Carpaților (Ucraina) şi se varsă în râul Laborec pe teritoriul Slovaciei. Printre cele mai frecvente microorganisme ale râului Uzh, a existat un nivel ridicat de rezistență la tetracicline, $\beta$-lactame și antibiotice din ultima linie de apărare (carbapeneme, fluorochinolone de generația a patra). Rezultatele analizei genetice moleculare indică prezența genelor de rezistență bla tetM, bla CTX-M, bla TEM și bla KPC în microorganisme din familia Enterobacteriaceae. 


\section{INTRODUCTION}

Due to industrialized production, there are many pharmaceuticals that became largely accessible worldwide, and their unintentional presence in various ecosystems have a negative impact (Burcea et al., 2020). The resistance development of microorganisms to antibiotic substances has become a global issue of this century. Although antibiotics have been leading medicines used in therapy, the current rapid development of resistance deteriorates their activity and efficacy (Yu et al., 2019). Antibiotic substances may accumulate and spread in the environment, first of all, in water and soils, which making them dangerous pollutants. As far as water takes part in the circulation of elements and is part of food chains, it may also be a key migration factor for genetic resistance determinants. After humans and animal have consumed antibiotics, most of the antibiotic substances that have not been fully digested and disposed of are eliminated from the body with excrements and enter rivers, lakes, and underground waters. The level of antibiotic resistance increases as they enter environmentally unfriendly mediums with a heightened level of pollutants. (Karkman et al., 2017)

Urbanized areas, where large amount of antibiotics enter wastewater treatment plants, are most saturated with antibiotic substances (Martinez et al., 2009). The environmental impact of the growing concentration of antibiotics has been studied insufficiently so far (Grehs et al., 2019), which does not give us a chance to evaluate the multi-resistant strains fully.

When the use of antibiotics grew by many times, the current pandemic triggered considerably the development of antibiotic resistance, which will inevitably result in the appearance of new "super-bacteria”, and it again emphasizes the importance of this issue.

Researches of the different regions point to the fast distribution of antibiotic resistance genes (ARGs), particularly - multi-resistant strains of Klebsiella spp., which are carriers of extended-spectrum beta-lactamases (ESBL) genes isolated from the Delhi River. In the Danube River (Budapest) were identified a number of multi-resistant microorganisms belonging to the Enterobacteriaceae family, and ESBL resistance genes were found in isolates Escherichia coli, Klebsiella pneumoniae, and Enterobacter spp. (Kittinger et al., 2016).

Multi-resistant isolates of Enterococcus faecium and Enterococcus faecalis were identified in the Vistula River (Poland) (Giebułtowicz et al., 2017). In that time, resistance genes CTX-M represented by subgroups CTX-M-1, CTX-M-2, and CTX-M-9 were identified in Enterobacteriaceae family representatives of the Mur River (Austria) (Zarfel et al., 2017).

A significant part of the research on antibiotic resistance is focused on clinical practice research, while this problem is poorly studied in natural ecosystems. But its role is equally important. Sanitary standards for surface water quality and centralized water supply do not provide the study of water for ARGs and even the identification of multi-resistant forms of microorganisms, which makes it impossible to control the ARG's spread.

The progressive evolution of antibiotic resistance leads to the study of mechanisms for developing new methods of surface water quality assessment that will allow continuous control of the circulation of ARGs in water. According these, study about the determination of dominant representatives of the Uzh River microbial communities and their sensitivity to antibiotics in territories with different levels of anthropogenic loading are relevant.

In this study, we aimed to investigate the presence and spread of antibiotic resistance genes in the surface waters organisms of the Uzh River to determine the current state of resistances. Researching into antibiotic resistence of aquatic ecosystems is an essential line of research. That will help study the profiles of antibiotics resistance genes in various urbanized hydroecosystems, which is a priority task elaborating technologies able to eliminate the antibiotics and inactivate the multi-resistant microorganisms and their resistance genes in wastewaters, avoiding cycles of contamination and environmental spread. 


\section{MATERIAL AND METHODS}

\section{Sampling points}

The materials used for the study were the surface waters of the Uzh River (Ukraine). The samples are taken during the summer period, taking into account the physical-chemical parameters of the water as previously researched by us and covered in the works (Bilkey and Nikolaichuk, 2017; Bilkei and Kryvtsova, 2018). Sampling was performed from eight-points, conventionally dividing the territory of the Uzh riverbed into the recreational zone: No. $1-$ upstream from the village of Volosianka; the technologically transformed zone - up-No. 2 and downstream No. 4 from the city of Perechyn and $100 \mathrm{~m}$ from the site where the Domoradzh Stream (derives from the chemical plant) flows into the Uzh River - No. 3; the urbanized zone - up-No. 5 and downstream from the city of Uzhhorod - No. 6 and agrarian - up-No. 7 and downstream the village of Storozhnytsia - No. 8) (Fig. 1).

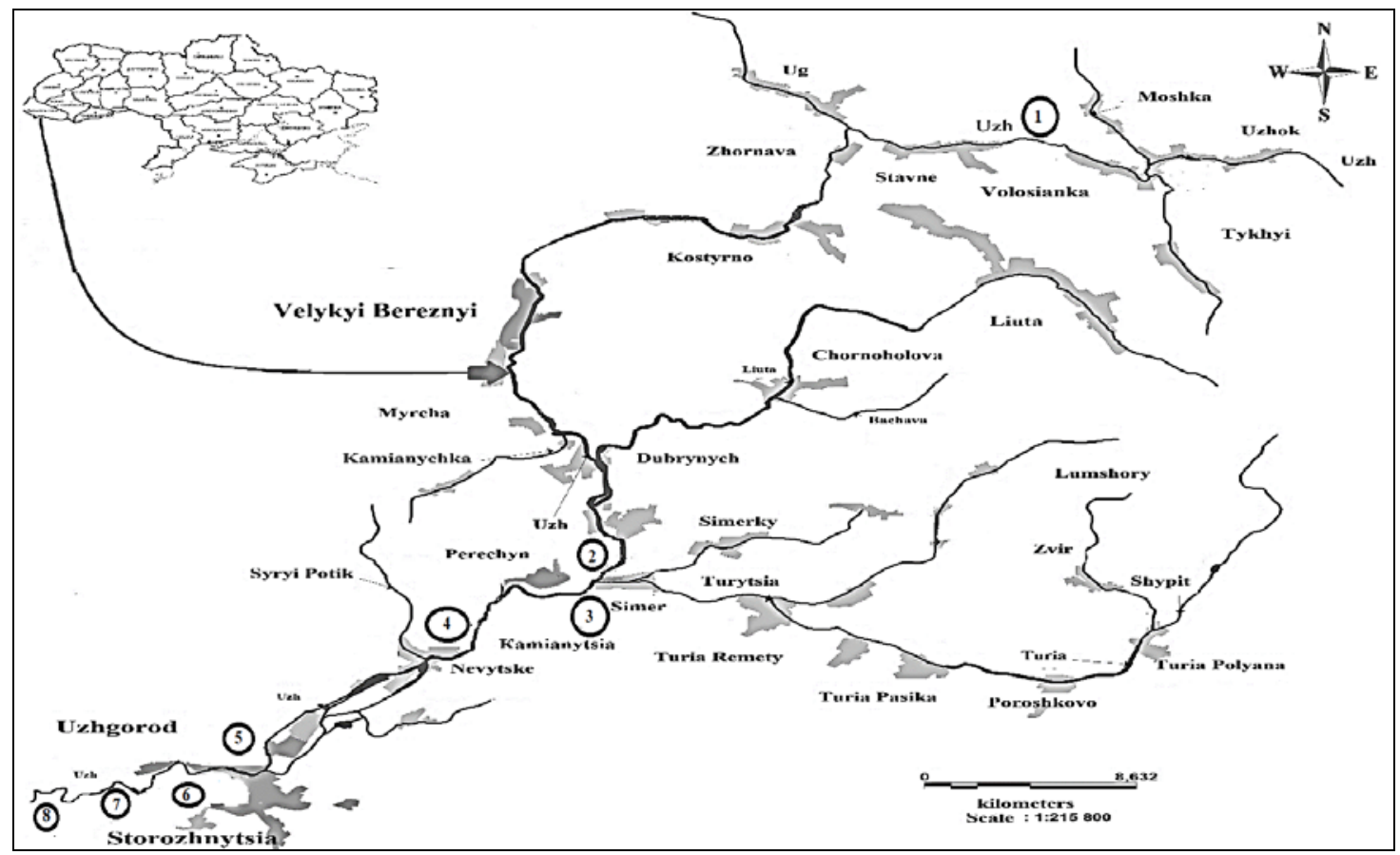

Figure 1: Uzh River study area (No. 1 - recreational zone; No. 2 - No. 4 - technologically transformed zone; No. 5 - No. 6 - urbanized zone; No. 7 - No. 8 - agrarian zone).

\section{Identification of isolated strains and analysis of antibiotic resistance}

The water samples collected in sterile vials with a volume of 1,000 ml, were corked with cotton stoppers covered with a paper cap. The water samples were analyzed two hours after sampling. Identification of microorganisms included studying the morphological characteristics of colonies on Hottinger agar $(\mathrm{pH} \pm 7.2)$ and further differentiation on selective media of Endo, Ploskirev, bismuth-sulfite agar. Chromogenic nutrient medium (Hi Crom UTI Agar, Modified HiMedia, India) used for one-stage isolation and direct identification of the most frequent and significant Enterobacteriaceae for sanitary microbiology. According to the results of biochemical tests (Enterotest 24 and 16) produced by ErbaLachema, Czech Republic, determining the generic and species affiliation of opportunistic bacteria was determined. Strains of Salmonella genome confirmed by Salmonella serum (Denka Seiken, Japan). 
Antibiotic resistance of the Enterobacteriaceae isolates determined by the Kirby-Bauer disk (HiMedia) diffusion method according to the European Committee on Antimicrobial Susceptibility Testing (EUCAST). Selection of antibiotics for testing water microorganisms, caused by the growth of the resistance to such groups of antibiotics (tetracyclines, $\beta$-lactams) among clinical strains in the investigated region. The isolates were screened for susceptibility to such antibiotics: ampicillin (AMP, $10 \mu \mathrm{g}$ ), ampicillin-sulbactam (AMP/S, 10/10 $\mu \mathrm{g}$ ), ceftriaxone (CTR, $30 \mu \mathrm{g}$ ), imipenem (IMP, $10 \mu \mathrm{g}$ ), cefuroxime (CXM, $30 \mu \mathrm{g}$ ), cefoperazonesulbactam (CFS, 75/30 $\mu \mathrm{g}$ ), meropenem (MRP, $10 \mu \mathrm{g}$ ); amikacin (AK, $30 \mu \mathrm{g}$ ); gentamicin (GEN- $10 \mu \mathrm{g}$ ); ciprofloxacin (CIP, $5 \mu \mathrm{g}$ ), levofloxacin (LE, five $\mu \mathrm{g}$ ), gatifloxacin (GAT, five $\mu \mathrm{g}$ ), norfloxacin (NX,10 $\mu \mathrm{g}$ ), ofloxacin (OF, two $\mu \mathrm{g}$ ), lomefloxacin (LOM, $30 \mu \mathrm{g}$ ); tetracycline (TE, $30 \mu \mathrm{g}$ ), and doxycycline (DO, $10 \mu \mathrm{g}$ ). The sterile filter paper disks (six mm in diameter) with antibiotics were placed on the plate previously inoculated with a microbial suspension and incubated at $37 \pm 2^{\circ} \mathrm{C}$ for 24 hours. The size of inhibition zone diameters surrounding the filter paper disc was measured and compared to the Zone Diameter Interpretive Standards. Each bacterial isolate is classified as susceptible (S), intermediate (I), or resistant (R) to antibiotics, according to the zone diameter interpretation standard recommended by the EUCAST (2018). Escherichia coli ATCC 25922 was used as a quality control strain to check the quality of the media and antibiotic discs and the accuracy of the testing procedure. The bacteriological analysis of the water and determination of its antibiotic susceptibility was conducted based on the Microbiological Laboratory of the Department of Genetics, Plant Physiology, and Microbiology of Uzhgorod National University (Ukraine).

\section{Detection of resistance genes}

Bacterial DNA were isolated by the method of temperature lysis in TE buffer. Colonies of daily cultures of the tested microorganisms were placed in a centrifuge tube with $500 \mu \mathrm{l}$ of sterile deionized water suspended with a shaker. Microbial cells precipitated by centrifugation at 10,000 $\mathrm{g}$ for one minute. The supernatant was removed, the sediment was resuspended in $100 \mu \mathrm{l}$ of TE buffer. The tubes were incubated in a solid-state thermostat for 20 minutes at $99^{\circ} \mathrm{C}$, and then centrifuged at $10,000 \mathrm{~g}$ for one minute. One $\mathrm{ml}$ of supernatant was used for polymerase chain reactions. The sets of reagents of "Lytekh" production (Russia) were used for the setting of PCR. The final volume of the reaction mixture was $25 \mu$. The reaction components were put in according to the manufacturer's instructions. Positive and negative control was included in the sets and performed according to the manufacturer's instructions. The resulting products were visualized by electrophoresis (0.5x TE buffer) in $2 \%$ agarose gel containing ethidium bromide, followed by viewing in a UV transilluminator. Polymerase chain reaction (PCR) was performed using a detector DTPrime Amplifier (DNA Technology; Russia).

The following sets of PCR-reagents for determination of resistance to antibiotics with electrophoretic end-point detection PCR (NPF Litekh; Russia) were used: the Resistance to carbapenems for identification of $b l a_{\mathrm{NDM}}$ genes; the Resistance to carbapenems for identification of $b l a_{\text {OXA-48 }}$ genes; the Resistance to cephalosporins for identification of $b l a_{\text {CTX-M }}$ genes; the Tetrapol set, for idenfinition of resistance to $b l a_{\text {tet-M }}$ tetracycline.

The other three groups of resistant genes $\left(b l a_{\mathrm{TEM}}, b l a_{\mathrm{KPC}}\right.$, and $\left.b l a_{\mathrm{SHV}}\right)$ were determined according to the protocol. Primers used to amplify the genes of beta-lactamase are presented in table 1. E. coli ATCC 25922 was used as a negative control. For positive controls were used, Klebsiella pneumoniae ATCC BAA-1705 (bla $a_{\mathrm{KPC}}$ genes), K. pneumoniae ATCC 5103 (bla TEM $_{\text {TE }}$ genes), and K. pneumoniae ATCC 700603 (bla ${ }_{\mathrm{SHV}}$ genes). 
Table 1: Primers used for the detection of antibiotic-resistant genes.

\begin{tabular}{|c|c|c|c|}
\hline $\begin{array}{c}\text { Gene } \\
\text { targeted }\end{array}$ & $\begin{array}{c}\text { Sequence } \\
\text { 5'-3' }\end{array}$ & $\begin{array}{c}\text { Aplicone size, } \\
\text { bp }\end{array}$ & References \\
\hline blaKPC & $\begin{array}{c}\text { 5'-GCGGAACCCCTATTTG-3' (F) } \\
\text { 5'-CTTGTCATCCTTGTTAGGCG-3' (R) }\end{array}$ & 798 & $\begin{array}{c}\text { Poirel et } \\
\text { al., } 2011\end{array}$ \\
\hline blaTEM & $\begin{array}{c}\text { 5'-GCGGAACCCCTATTTG-3' (F) } \\
\text { 5'-ACCAATGCTTAATCAGTGAG-3'(R) }\end{array}$ & 964 & $\begin{array}{c}\text { Olesen et } \\
\text { al., 2004 }\end{array}$ \\
\hline blaSHV & $\begin{array}{c}\text { 5'-TTATCTCCCTGTTAGCCACC-3' (F) } \\
\text { 5'-GATTTGCTGATTTCGCTCGG-3' (R) }\end{array}$ & 795 & $\begin{array}{c}\text { Arlet et } \\
\text { al., } 1997\end{array}$ \\
\hline
\end{tabular}

\section{RESULTS AND DISCUSSION}

\section{Facultative microbial communities in Uzh River water}

The results of our research showed that microorganisms of the Enterobacteriaceae predominantly represented the gram-negative constituent of the microbial communities of the Uzh River. Antibiotic-resistant microorganisms were not detected in the recreational area. It was also established that the most significant number of opportunistic microorganisms fell on the technologically transformed territory and lower courses of the river within the boundaries of the agrarian area. The change of the species composition of microorganisms is known to indicate the level of transformation of a hydro ecosystem on the whole (Harnisz et al., 2015). Bearing in mind that enterobacteria constituted the central part of the microbiocenosis of the river and were distinguished by a broad species spectrum, we conducted a quantitative assessment of the microorganisms' domination level. Analyzing the species ratio of isolated microorganisms from natural waters, the most common bacteria were Escherichia species, which were found almost along the entire length of the river and dominated the quantitative ratio in the technogenically transformed area (64.2\%) and the urbanized area (59.2\%) (Fig. 2).

However, microorganisms of the genus Klebsiella (17.2\%) also reached moderately high values in the urbanized territory, while high titers of Citrobacter (47.1\%) were recorded in the agricultural area.

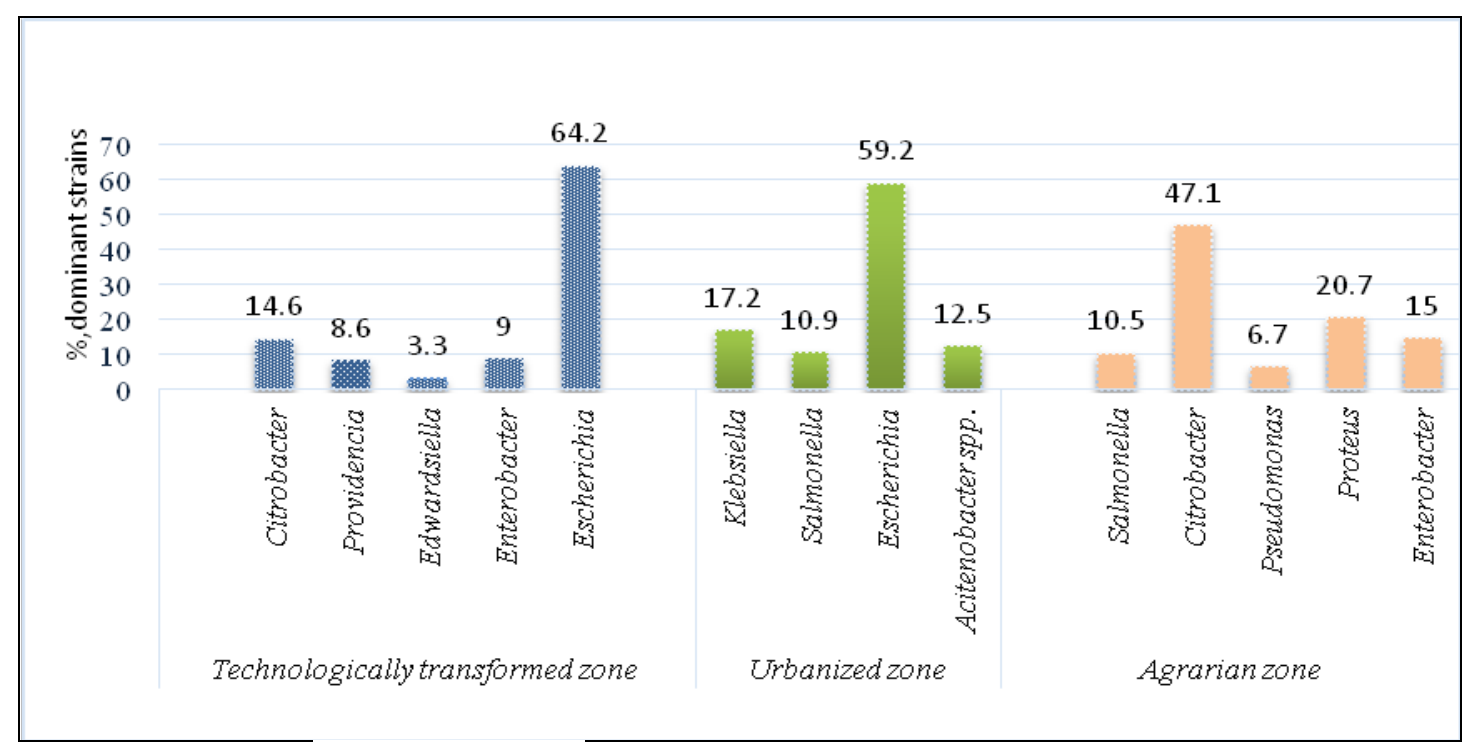

Figure 2: The predominant microorganisms isolated from Uzh River water. 


\section{Antibiotic resistance analysis of the most common microorganisms isolated from river water samples}

The most commonly used strains were chosen for determining antibiotic susceptibility tests; they were selected and differentiated by investigation points. In the area of technologically transformed area such genera were allocated: the city of Perechyn Escherehia $(\mathrm{n}=20), 100 \mathrm{~m}$ from the site where the Domoradzh Stream flows into the Uzh River Escherichia $(\mathrm{n}=114)$, Edwardsiella $(\mathrm{n}=$ nine), Citrobacter $(\mathrm{n}=39)$, Enterobacter $(\mathrm{n}=$ 24), downstream from the city of Perechyn - Escherichia $(\mathrm{n}=37)$, Providencia $(\mathrm{n}=23)$. In the urbanized area, namely the city of Uzhhorod - Klebsiella $(\mathrm{n}=44)$, Acitenobacter spp. ( $\mathrm{n}=$ $32)$ and beyond the city - Escherichia $(\mathrm{n}=87)$ and Salmonella $(\mathrm{n}=28)$. In the agrarian territory, such microorganisms were dominated: Citrobacter $(n=98)$, Proteus $(n=43)$ in the village of Storozhnitsa and beyond - Salmonella $(\mathrm{n}=22)$, Enterobacter $(\mathrm{n}=31)$, and Pseudomonas $(\mathrm{n}=14)$.

The results of the studies are presented in figures 3-5.

According to figures $3-5$, the highest degrees of resistance are observed technogenically transformed and agricultural areas. Resistance indices are growing downstream of the river with a marked increase outside the settlements and at the plant's wastewater discharge point. Outside the plant, there is a high level of resistance to beta-lactams and tetracyclines. Compared to other areas, the number of multi-resistant forms and resistance to carbapenems and "protected" antibiotics (ampicillin-sulbactam, cefoperazone-sulbactam) is growing. The area outside the plant is contaminated with heavy metals and nitrogen compounds, which may increase the antibiotic resistance level (Bilkey and Nikolaichuk, 2017; Bilkei and Kryvtsova, 2018). High concentrations of heavy metals contribute to the spread and accumulation of ARGs (Martins et al., 2014). Downstream of the river, within the city, there is a slightly higher degree of sensitivity to antibiotics than in anthropogenically loaded areas; however, the trend towards a relatively high level of resistance to tetracyclines and penicillins persists. It is more facilitated by the uncontrolled wastewater discharge into the river system. However, one of the reasons may include natural resistance developed under various environmental factors (Finley et al., 2013). In the agricultural area, in the lower reaches of the river, resistance to second-generation fluoroquinolones is growing, and resistance to antibiotics of natural origin (ampicillin, gentamicin, and tetracycline) remains invariably at high level. According to Guardabassi et al. (2000) research, resistance to quinolones and tetracyclines is really widespread for the microorganisms of natural waters. A low resistance percentage is typical for carbapenems (imipenem and carbapenem) and third-generation cephalosporins (ceftriaxone). Based on these results, the most significant transformation is standard for an antibiotic-resistant anthropogenically loaded area, where a high level of contamination is observed. 


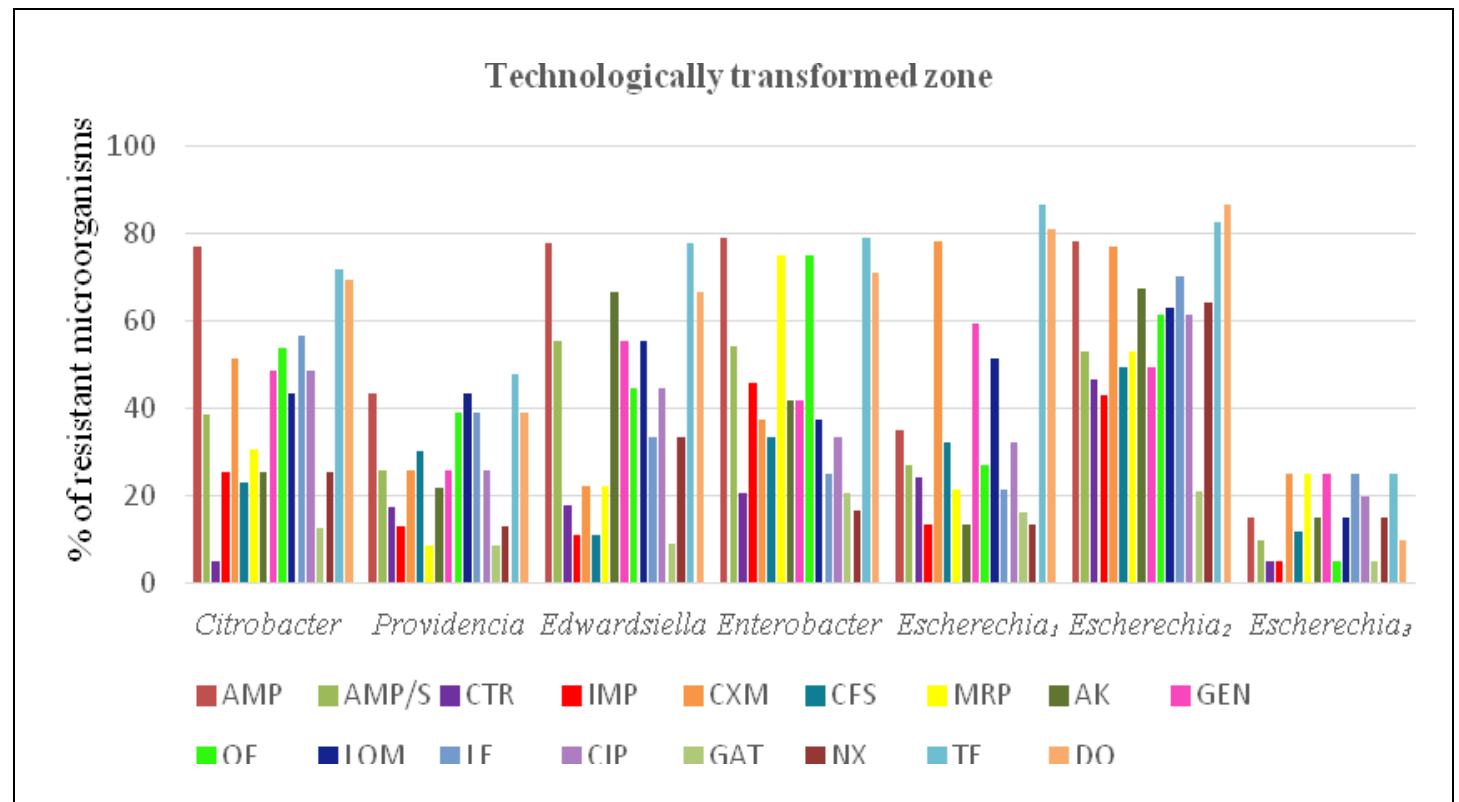

Figure 3: Antibiotic resistance of microorganisms isolated from technological territory, Citrobacter, Edwardsiella, Enterobacter, Escherichia ${ }^{1}$ genera - outside the plant; Providencia, Escherichia ${ }^{2}$ genera - outside the city Perechyn; Escherichia ${ }^{3}$ genus - to the city Perechyn.

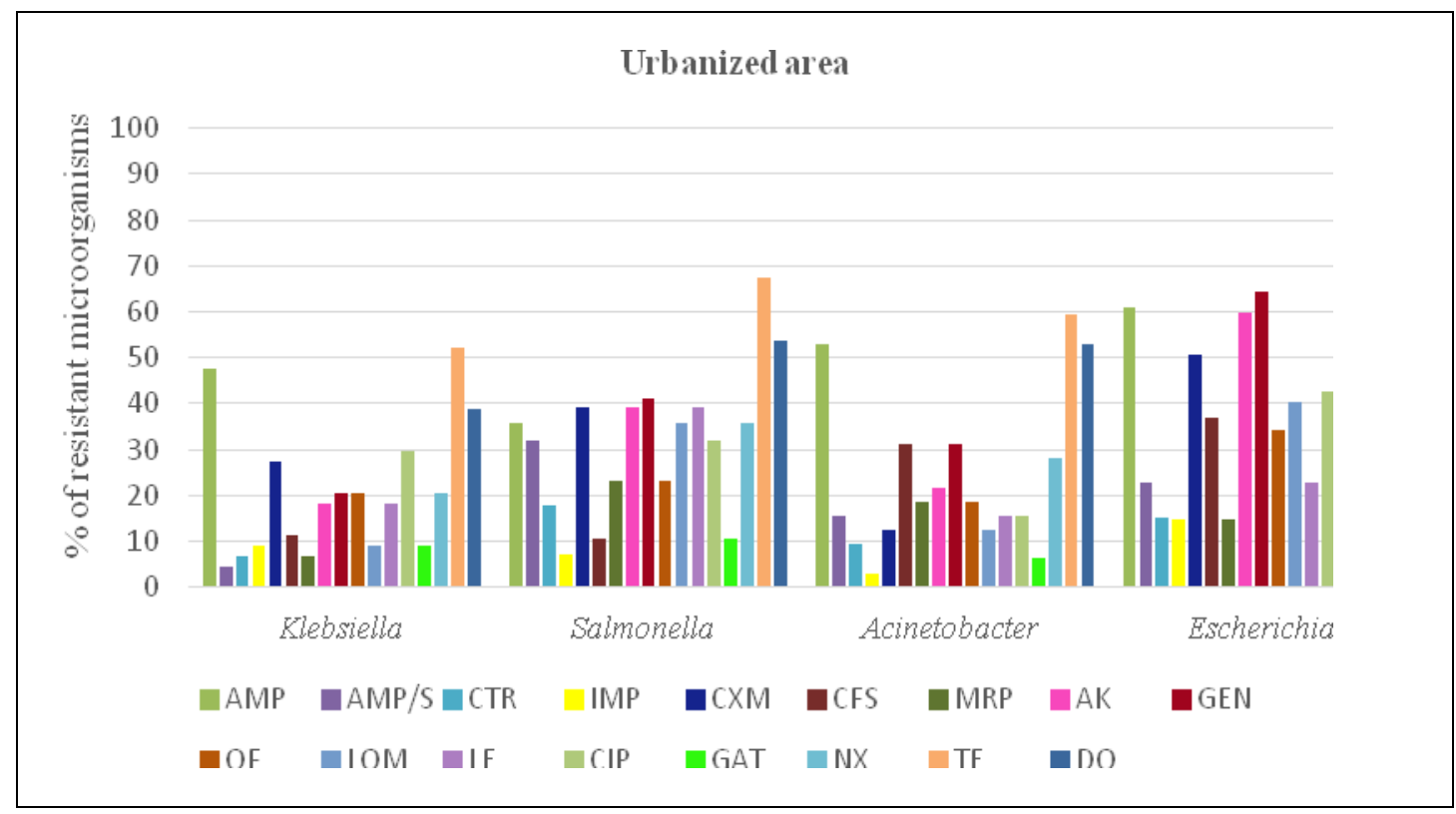

Figure 4: Antibiotic resistance of microorganisms isolated from the urbanized territory, Klebsiella and Acinetobacter spp. genera - to the city Uzhhorod; Salmonella and Escherichia genera - outside the city Uzhhorod. 


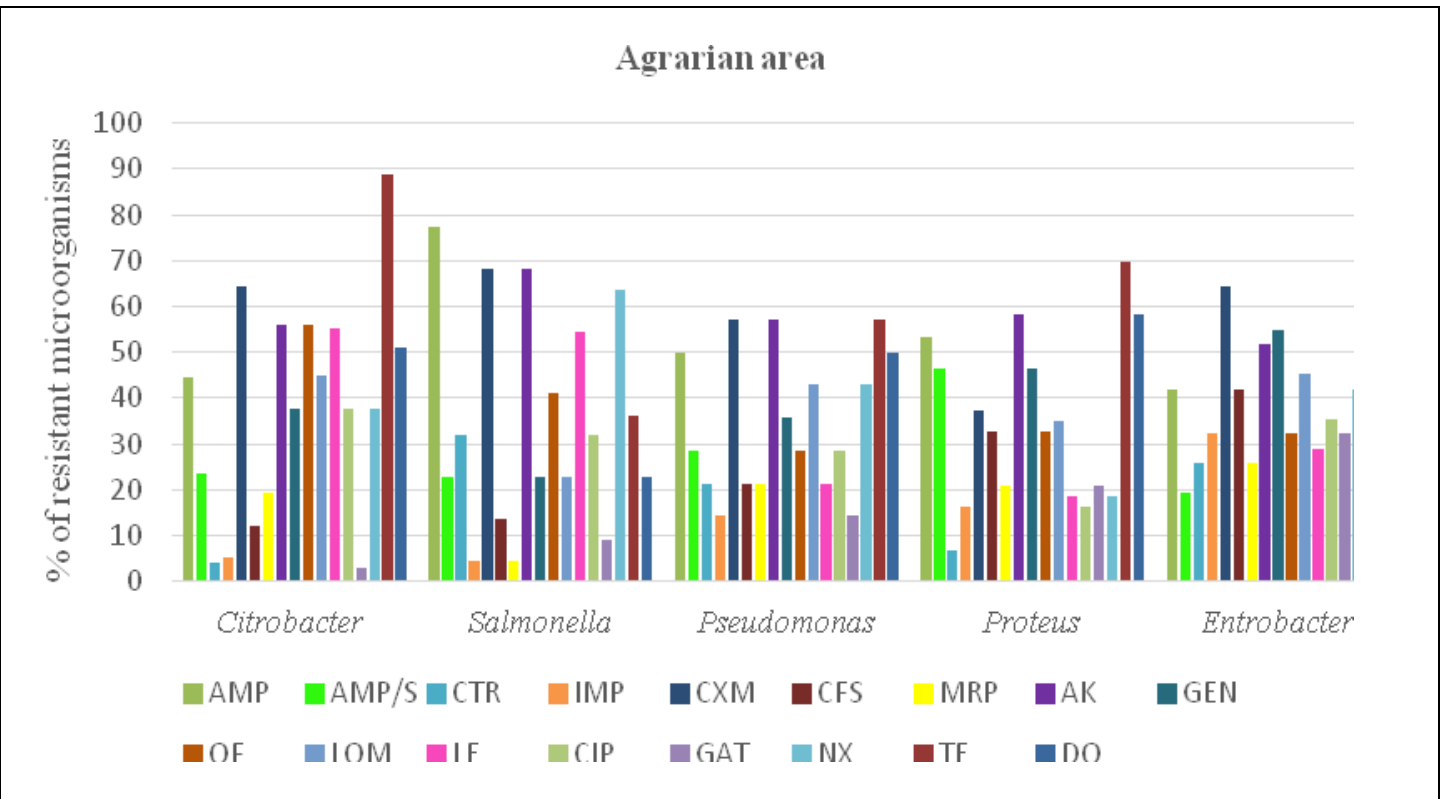

Figure 5: Antibiotic resistance of microorganisms isolated from the agrarian territory, Citrobacter and Proteus - to the village;

Salmonella, Pseudomonas, and Enterobacter genera - outside the village.

Investigation of antibiotic resistance genes of isolated microorganisms

The results of the molecular genetic analysis made it possible to determine the presence of ARGs of isolated multiresistant microorganisms in the reservoir. To define the genetic determinants of resistance, we have selected multi-resistant gram-negative microorganisms that dominated the microbiome of the studied areas (Fig. 6).

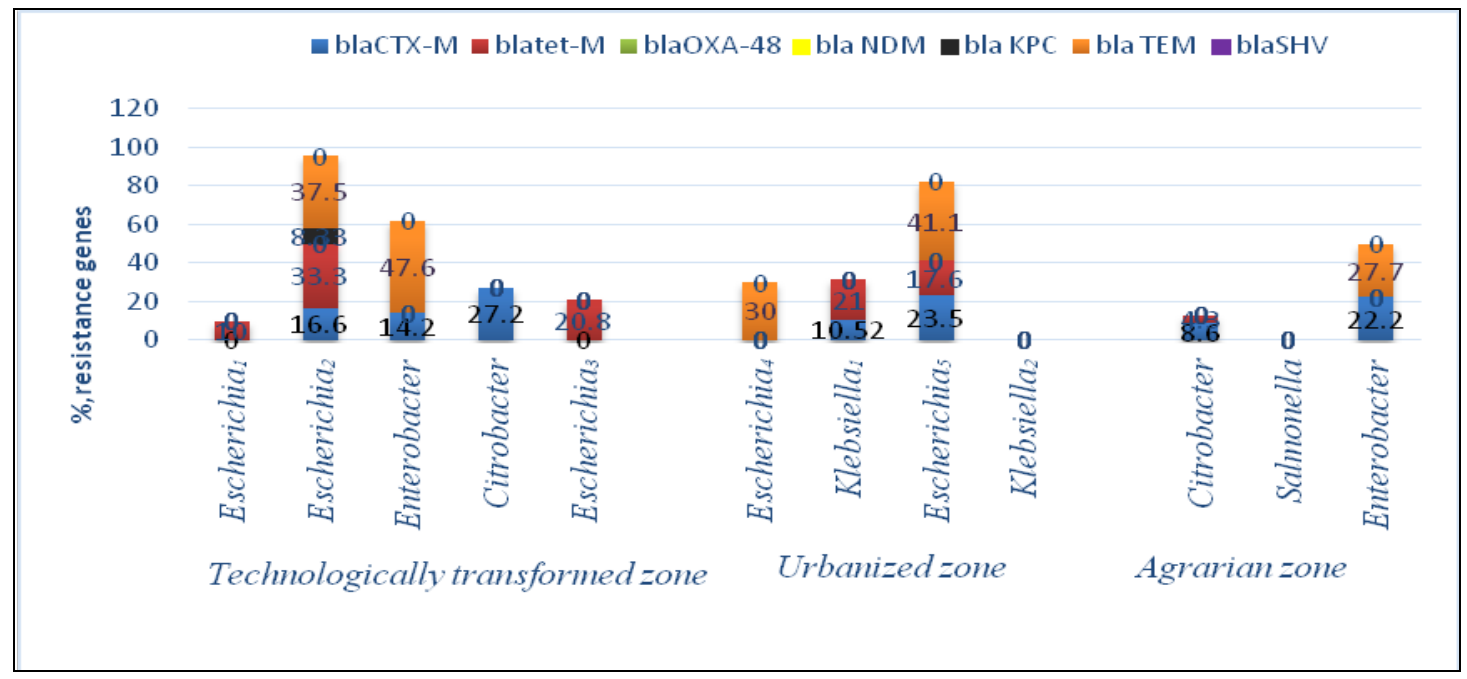

Figure 6: Genetic determinants of resistance of multidrug-resistance microorganisms isolated from the Uzh River, Escherichia - to the city Perechyn; Escherichia, Enterobacter, and Citrobacter near the Domoradzh Stream, Escherichia - outside the city Perechyn; Escherichia, Klebsiella - to the city Uzhhorod; Escherichia and Klebsiella - outside the city Uzhhorod; Salmonella and Enterobacter - outside the village Storozhnytsia; Citrobacter - to the the village Storozhnytsia. 
The presence of tetracyclines and b-lactamase resistance genes $\left(b l a_{\text {TEM }}\right.$ and $\left.b l a_{\text {CTX-M }}\right)$ were primarily identified in a group of strains of the genus Escherichia from the technogenically transformed territory. The results of the microbiological analysis also have shown a high level of phenotypic resistance to these groups of antibiotics among the identified microorganisms. In addition, genes encoding carbapenemases $\left(b l a_{\mathrm{KPC}}\right)$ have been revealed in this area; these are less common in natural environments and are more dangerous since they provoke the gradual development of general resistance to drugs (Adegoke et al., 2020). At the same time, according to recent studies, carbapenem-resistant genes are increasingly found within the territory of Europe (Nordmann et al., 2011). A significant prevalence of ESBL genes such as bla $a_{\text {TEM }}$ and $b l a_{\text {СтX-м }}$ has been observed in the urbanized area. The largest percentage of bla $a_{\mathrm{TEM}}$ genes have been revealed among members of the genus Escherichia. According to the results of previous studies, bacteria of the genus Escherichia are characterized by a higher proportion of the spread of resistance (i.e. ESBL) in natural communities than other enterobacteria (Brolund and Sandegren, 2016). A likely source of resistance genes in a given area is municipal wastewater, which, as it is known, can act as reservoirs of resistant forms of microorganisms and genetic determinants of resistance, as well as a determining factor in the formation of environmental resistance (Karkman et al., 2019). A detrimental consequence of the significant proliferation of ESBL genes may be the development of various resistance mechanisms, including the ability to provide resistance to carbapenem due to further chromosome mutations of porine (Lutgring and Limbago, 2016). ESBLs have been identified on the territory exposed to the agricultural sector; the largest share of ESBLs falls on the bla $a_{\text {СтХ-M }}$ genes encoding quinolone resistance. The results of microbiological studies have also shown an increase in resistance to second- and thirdgeneration fluoroquinolones in this area.

This study has revealed the appearance of more than one beta-lactamase in the same isolate; $b l a_{\mathrm{TEM}}$ genes have been found both alone and in combination with $b l a_{\text {tet-M }}$ genes. It indicates the evolution of microorganisms to antimicrobial resistance.

The results of the study showed a significant presence of ARGs in water samples. Thus, getting into the environment, ARGs may contribute new strains of microorganisms having drug resistance.

\section{CONCLUSIONS}

Nowadays, antibiotic resistance is one of the most severe threats to human health. The obtained results provide a basis to believe that the indicator of antibiotic resistance can be used as a marker of anthropogenic activity. One of the necessary practical implementations that need to be done is developing and applying the methods to quantify actual resistance genes in the aquatic systems. The next important direction will be to build a better separation of human and animal sources, including methods with clearly distinguished human and agricultural sources of resistance genes that will help develop strategies for reducing the effects of pollution. It is also really important to create and implement a monitoring system for antibiotic-resistant bacteria and their resistance genes in natural waters and on the way to different consumers. Although the problems of ARGs pollution have attracted some attention in recent years, there is still a need for more effort to reduce the possibility of ARGs entering and spreading into the environment. 


\section{ACKNOWLEDGEMENTS}

The present study is a part of the research project at the Department of Genetics, Plant Physiology and Microbiology of Uzhhorod National University (Ukraine) "Research of genetic, physiological, and biochemical mechanisms of various organization level biological systems adaptation in the anthropogenic loading conditions”, No. 0115U003902. 


\section{REFERENCES}

1. Adegoke A. A., Fatunla O. K. and Okoh A. I., 2020 - Critical threat associated with carbapenem-resistant gram-negative bacteria: prioritizing water matrices in addressing total antibiotic resistance, Annals of Microbiology, 70, 1, 1-13.

2. Arlet G., Rouveau M. and Philippon A., 1997 - Substitution of alanine for aspartate at position 179 in the SHV-6 extended-spectrum $\beta$-lactamase, FEMS Microbiology Letters, 152, 1, 163-167.

3. Bilkey M. V. and Nikolaichuk V. I., 2017 - The distribution of heavy metals content in the bottom deposits of the trans-border Uzh River system, Biosystems Diversity, 25, 2, 145-153. (in Ukrainian)

4. Bilkei M. V. and Kryvtsova M. V., 2018 - Spatiotemporal characteristics of microbiological and hydrochemical indicators of the quality of surface waters of the Uzh River (Ukraine), Bìoresursi ì Prirodokoristuvannâ, 10, 5-6, 24-37. (in Ukrainian)

5. Brolund A. and Sandegren L., 2016 - Characterization of ESBL disseminating plasmids, Infectious diseases, 48, 1, 18-25.

6. Burcea A., Boeraş I., Mihuţ C.-M., Bănăduc D., Matei C. and Curtean-Bănăduc A., 2020 Adding the Mureş River basin (Transylvania, Romania) to the list of hotspots with high contamination with pharmaceuticals, Sustainability, 12, 23, 10197, doi:10.3390/su122310197, Special Issue: Landscape, water, ground, and society sustainability under Global change scenarios, 19.

7. EUCAST, 2018 - European Committee on Antimicrobial Susceptibility Testing, http://www.eucast.org/fileadmin/src/media/PDFs/EUCAST_files/Breakpoint_tables/v_8.0_Brea kpoint_Tables.pdf

8. Finley R. L., Collignon P., Larsson D. J., McEwen S. A., Li X. Z., Gaze W. H. and Topp E., 2013 - The scourge of antibiotic resistance: the important role of the environment, Clinical infectious diseases, 57, 5, 704-710.

9. Giebułtowicz J., Tyski S., Wolinowska R., Grzybowska W., Zaręba T., Drobniewska A. and Nałęcz-Jawecki G., 2017 - Occurrence of antimicrobial agents, drug-resistant bacteria, and genes in the sewage-impacted Vistula River (Poland), Environmental Science and Pollution Research, 25, 6, 5788-5807.

10. Grehs B., Lopes A. R., Moreira N., Fernandes T., Linton M., Silva A., Manaia C. M., Carissimi E. and Nunes O. C., 2019 - Removal of microorganisms and antibiotic resistance genes from treated urban wastewater: A comparison between aluminium sulphate and tannin coagulants, Water research, 166, 115056.

11. Guardabassi L., Dalsgaard A., Raffatellu M. and Olsen J. E., 2000 - Increase in the prevalence of oxolinic acid resistant Acinetobacter spp. observed in a stream receiving the effluent from a freshwater trout farm following the treatment with oxolinic acid-medicated feed, Aquaculture, 188, 3-4, 205-218.

12. Harnisz M., Korzeniewska E. and Gołaś I., 2015 - The impact of a freshwater fish farm on the community of tetracycline-resistant bacteria and the structure of tetracycline resistance genes in river water, Chemosphere, 128, 134-141.

13. Karkman A., Lehtimäki J. and Ruokolainen L., 2017 - The ecology of human microbiota: dynamics and diversity in health and disease, Annals of the New York Academy of Sciences, 1399, 1, 78-92.

14. Karkman A., Pärnänen K. and Larsson D. J., 2019 - Fecal pollution can explain antibiotic resistance gene abundances in anthropogenically impacted environments, Nature communications, 10, 1, 1-8.

15. Kittinger C., Lipp M., Folli B., Kirschner A., Baumert R., Galler H., Grisold A. J., Luxner J., Weissenbacher M., Farnleitner A. H. and Zarfel, G., 2016 - Enterobacteriaceae isolated from the River Danube: antibiotic resistances, with a focus on the presence of ESBL and Carbapenemases, PloS one, 11, 11: e0165820. 
16. Lutgring J. D. and Limbago B. M., 2016 - The problem of carbapenemase-producingcarbapenem-resistant-Enterobacteriaceae detection, Journal of clinical microbiology, 54, 3, 529534.

17. Martinez J. L., Fajardo A., Garmendia L., Hernandez A., Linares J. F., Martínez-Solano L. and Sánchez M. B., 2009 - A global view of antibiotic resistance, FEMS Microbiology Reviews, 33, 1, 44-65.

18. Martins V. V., Zanetti M. O., Pitondo-Silva A. and Stehling E. G., 2014 - Aquatic environments polluted with antibiotics and heavy metals: a human health hazard, Environmental science and pollution research international, 21, 9, 5873-5878.

19. Nordman P., Naas T. and Poirel L., 2011 - Global spread of carbapenemase-producing Enterobacteriaceae, Emerging infectious diseases, 17, 10, 1791.

20. Olesen I., Hasman H. and Møller Aarestrup F., 2004 - Prevalence of $\beta$-lactamases among ampicillin-resistant Escherichia coli and Salmonella isolated from food animals in Denmark, Microbial drug resistance, 10, 4, 334-340.

21. Poirel L., Walsh T. R., Cuvillier V. and Nordmann P., 2011 - Multiplex PCR for detection of acquired carbapenemase genes, Diagnostic Microbiology Infectious Disease, 70, 119-23.

22. Yu X., Sharma V. K. and Li H., 2019 - Environmental antibiotics and antibiotic resistance: from problems to solutions, Frontiers of Environmental Science and Engineering, 13, 3, 47.

23. Zarfel G., Lipp M., Gürtl E. Folli B., Baumert R. and Kittinger C., 2017 - Troubled water under the bridge: screening of river Mur water reveals dominance of CTX-M harbouring Escherichia coli and for the first time an environmental VIM-1 producer in Austria, The Science of the total environment, 593-594, 399-405. 